\title{
STRATEGI PENINGKATAN KUALITAS PENGELOLAAN KAWASAN WISATA PANTAI AMAL KOTA TARAKAN SEBAGAI DAYA TARIK EKOWISATA
}

\author{
STRATEGY TO IMPROVE QUALITY OF PANTAI AMAL TOURISM AREA \\ MANAGEMENT IN TARAKAN AS AN ACOTOURISM FASCINATION
}

\author{
Nurdin $^{1)}$, Witri Yuliawati ${ }^{2)}$ \\ ${ }^{1) 2)}$ Universitas Borneo Tarakan
}

\begin{abstract}
Abstrak : Tujuan dari penelitian ini adalah untuk merumuskan strategi dalam meningkatkan kualitas pengelolaan kawasan wisata Pantai Amal dan penentuan strategi alternatif yang menjadi prioritas dalam mengoptimalkan peningkatan kualitas pengelolaan kawasan wisata Pantai Amal. Metode analisis data yang digunakan dalam penelitian ini adalah metode analisis deskriptif pertama yang digunakan untuk menggambarkan potensi dan kendala yang ada di objek wisata pantai Amal, yang kedua menggunakan analisis SWOT untuk merumuskan strategi dalam meningkatkan pengelolaan pariwisata Pantai Amal. area dan yang ketiga menggunakan metode AHP dalam memprioritaskan strategi yang telah dirumuskan. Hasil penelitian ini menunjukkan bahwa strategi dalam meningkatkan kualitas pengelolaan kawasan wisata Pantai Amal sebagai daya tarik ekowisata adalah strategi SO (kekuatan-peluang). Strategi prioritas pertama dari aspek manajemen adalah meningkatkan manajemen pengelolaan Pantai Amal, kemudian mengoptimalkan pengelolaan objek wisata, melatih / membina kerajinan rakyat berdasarkan potensi yang ada, mengembangkan objek wisata yang berbeda dengan pesaing dan belajar membandingkan dengan yang lain objek wisata. Kedua aspek infrastruktur, yaitu dengan melengkapi sarana dan prasarana dasar, meningkatkan pengelolaan informasi wisata Pantai Amal, melakukan standarisasi keamanan dan pemeliharaan secara berkala. Ketiga dari aspek ekonomi, yaitu dengan pengembangan objek wisata sebagai daya tarik ekowisata, menciptakan iklim investasi dan mengembangkan serta menghadirkan produk-produk baru khas wisata Pantai Amal. Keempat aspek sosial budaya, yaitu diversifikasi kegiatan wisata atau objek wisata baru, pengadaan kegiatan artistik multiguna, pengadaan kegiatan budaya tradisional khas Kota Tarakan dan sosialisasi pengawasan dan perawatan kawasan objek wisata.
\end{abstract}

Kata kunci: Manajemen kualitas, Pantai Amal, Strategi Prioritas, Strategi Peningkata

Abstract : The purpose of this study is to formulate strategies in improving the quality of the management of Amal Beach tourism area and the determination of alternative strategies that become priority in optimizing the quality improvement of the management of the Amal Beach tourism area. The method of data analysis used in this research is the first method of descriptive analysis used to describe the potential and constraints that exist in the attractions of the Amal beach, the second using SWOT analysis to formulate strategies in improving the 
management of the Amal Beach tourism area and the third using AHP method in prioritize the strategy that has been formulated. The results of this study indicate that the strategy in improving the quality of the management of Amal Beach tourism area as an ecotourism attraction is the SO (strength-opportunity) strategy. The first priority strategy from the management aspect is to improve the management of Amal Coastal management, then optimize the management of tourism object, training/fostering of people's craft based on existing potency, developing the different tourism object with the competitor and study comparing with other tourism object. Both of the infrastructure aspects, namely by completing basic facilities and infrastructure, improve the management of tourist information Coastal Amal, standardize security and maintenance on a regular basis. Third from the economic aspect, that is with the development of tourism object as the attraction of ecotourism, creating an investment climate and developing and presenting new products typical of Amal Beach tourism. Fourth of social culture aspect, that is by diversification of tourism activity or new tourist attraction, procurement of multipurpose artistic activity, procurement of traditional cultural activity typical of Tarakan City and socialization of supervision and care of tourism object area.

Keywords : Quality management, Amal Beach, Priority Strategy, Improvement Strategy

\section{LATAR BELAKANG}

Pengembangan pariwisata merupakan salah satu program pemerintah yang akhir-akhir ini banyak disoroti oleh media massa di Indonesia, yang mana memberikan andil yang cukup besar bagi penambah devisa negara di luar sektor nonmigas. Program pengembangan pariwisata terus dilakukan oleh pemerintah dengan harapan dapat meningkatkan jumlah wisatawan mancanegara dan wisatawan nusantara yang pada akhirnya akan mendatangkan keuntungan bagi pemasukan keuangan negara. Pengeluaran belanja oleh para wisatawan diharapkan meningkatkan pendapatan penduduk setempat dan memperluas wawasan kebudayaan dibidang pariwisata sebagai akibat kontak budaya wisatawan dengan wisatawan yang berada dari luar lingkungan budaya setempat.

Pengelolaan pariwisata yang berkelanjutan dapat memberikan dampak positif bagi semua pihak, dari segi material dengan meningkatnya pendapatan masyarakat. Keuntungankeuntungan lainnya dengan adanya obyek pariwisata adalah dibangunnya sarana-sarana yang menuju lokasi pariwisata tersebut, misalnya transportasi, penginapan, kios-kios tempat menjual cindera mata warung makan dan lain sebagainya. Di samping itu pula akan terbukalah wawasan masyarakat tentang dunia luar dengan adanya interaksi langsung antara penduduk setempat dengan para wisatawan baik domestik maupun mancanegara. Pembangunan kepariwisataan di daerah adalah merupakan bagian dari pembangunan daerah secara 
keseluruhan, yang diharapkan dapat memberikan dampak positif seperti terbukanya kesempatan kerja, meningkatkan pendapatan daerah dan masyarakat serta dapat mengarahkan kegiatan yang positif bagi masyarakat dan generasi muda.

Peningkatan pengunjung dan penerimaan pada setiap tahunnya menjadi pendorong utama dalam pengembangan karena sudah pasti tempat wisata ini menarik, dan pengunjung atau wisatawan adalah objek utama yang mendukung untuk dikembangkannya tempat wisata ini. Dapat kita ketahui bahwa masyarakat sekarang pada umumnya sudah sadar akan pentingnya rekreasi sehingga tempat rekreasi di Kota Tarakan khususnya Pantai Amal pasti akan menjadi tujuan bagi masyarakat sekitar dan juga wisatawan luar daerah yang sudah mengetahui keberadaannya. Lebih lagi Pantai Amal salah satu objek wisata pantai yang banyak diminati oleh wisatawan dilihat dari jumlah pengunjung yang terus mengalami peningkatan dari beberapa tahun terakhir.

Namun pengadaan sarana dan prasarana dasar dalam pengembangan objek wisata Pantai Amal ini masih belum optimal dan banyaknya sampah yang berserakan mengubah pemandangan yang sejuk menjadi tidak menarik. Promosi yang dilakukan pemerintah hanyalah sebatas menuliskan informasi melalui web masih kurang optimal karena kurangnya pembaruan informasi mengenai perkembangan objek wisata Pantai Amal. Padahal jika dikoordinasikan dan melibatkan masyarakat pasti akan membantu dalam program pengembangan, sehingga masyarakat juga merasa ikut memiliki daerah tersebut dan akan optimal dalam melakukan perannya karena merasakan secara langsung efek yang diberikan.

Berdasarkan pemaparan latar belakang masalah di atas maka penulis tertarik untuk mengkaji strategi peningkatan kualitas pengelolaan kawasan wisata Pantai Amal sebagai daya tarik ekowisata.

\section{RUMUSAN MASALAH}

Adapun rumusan masalah penelitian ini adalah :
1. Bagaimana strategi dalam meningkatan kualitas pengelolaan kawasan wisata Pantai Amal sebagai daya tarik ekowisata?

2. Apa strategi prioritas pengembangan kawasan wisata Pantai Amal Kota Tarakan?

\section{TUJUAN PENELITIAN}

Adapun tujuan dari penelitian ini adalah untuk :

1. merumuskan strategi dalam meningkatan kualitas pengelolaan kawasan wisata Pantai Amal sebagai daya tarik ekowisata.

2. menganalisis strategi prioritas pengembangan kawasan wisata Pantai Amal Kota Tarakan.

\section{TINJAUAN PUSTAKA}

$\underline{\text { Pariwisata }}$

Undang-Undang Republik Indonesia/UU RI Nomor 10 Tahun 2009 bab 1 Pasal 1 no.3 "pariwisata adalah berbagai macam kegiatan 
wisata dan didukung berbagai fasilitas serta layanan yang disediakan oleh masyarakat, pengusaha, pemerintah dan pemerintah daerah". Pariwisata menurut Undang-undang Nomor 9 Tahun 1990 pada bab 1 pasal 1 nomor 3 "pariwisata adalah segala sesuatu yang berhubungan dengan wisata, termasuk pengusaha objek dan daya tarik wisata serta usahausaha yang terkait dengan bidang tersebut". Artinya semua kegiatan dan urusan yang ada kaitannya dengan perencanaan, pengaturan, pelaksanaan, pengawasan, pariwisata baik yang dilakukan oleh pemerintah, pihak swasta dan masyarakat disebut kepariwisataan. Menurut definisi yang luas pariwisata adalah "perjalanan dari suatu tempat ke tempat lain, bersifat sementara, dilakukan perorangan maupun kelompok, sebagai usaha mencari keseimbangan atau keserasian dan kebahagiaan dengan lingkungan hidup dalam dimensi sosial, budaya, alam dan ilmu" (Spillane 1991:21).

$\underline{\text { Pengembangan Pariwisata }}$

Yoeti

(2008:273)

berpendapat bahwa "pengembangan adalah usaha atau cara yang dilakukan untuk memajukan sebuah hal yang sudah ada". Jika dikaitkan dengan penelitian ini pengembangan pariwisata berarti usaha atau cara untuk memajukan serta mengembangkan pariwisata yang telah ada. Sedangkan menurut Mussanef dalam Parlindungan et al (2016:54) pengembangan pariwisata adalah "kegiatan-kegiatan serta usaha-usaha yang dilakukan secara terkoordinasi demi menarik wisatawan, menyediakan sarana dan prasarana, jasa fasilitas serta barang yang diperlukan untuk memenuhi kebutuhan wisatawan".

\section{$\underline{\text { Ekowisata }}$}

Ekowisata dapat dilihat sebagai suatu konsep pengembangan pariwisata berkelanjutan yang bertujuan untuk mendukung upayaupaya pelestarian lingkungan (alam dan budaya) dan meningkatkan partisipasi masyarakat dalam pengelolaannya (Satria, 2009:37). Oleh karena itu, peran masyarakat sangat dibutuhkan dalam mengoptimalkan pengelolaan kawasan wisata sehingga keberlangsungan pelestarian lingkungan alam dan budaya tetap terjaga, yang merupakan daya tarik bagi suatu objek wisata.

\section{$\underline{\text { Pengertian Strategi }}$}

Strategi pengembangan
menurut Prasetyo (2013:155)
mengatakan bahwa "alasan suatu
daerah mengembangkan sektor
pariwisatanya adalah sebagai berikut. Pengembangan pariwisata merupakan suatu tindakan yang menentukan dalam semua program pengembangan wilayah dan masyarakat". Pengertian strategi pengembangan Menurut Rangkuti (2003:3) menyatakan bahwa; Strategi merupakan kegiatan perusahaan untuk mencari kesesuaian antara kekuatankekuatan internal perusahaan dan kekuatan-kekuatan eksternal (peluang dan ancaman) suatu pasar. Adapun kegiatannya meliputi pengamatan secara hati-hati 
terhadap persaingan, peraturan tingkat inflasi, siklus bisnis, keunggulan, dan harapan konsumen serta faktor-faktor lain yang dapat mengidentifikasi peluang dan ancaman.

\section{METODOLOGI PENELITIAN}

$\underline{\text { Desain Penelitian }}$

Jenis penelitian yang digunakan dalam penelitian ini adalah penelitian deskriptif dengan pendekatan kuantitatif dan kualitatif. Penelitian ini menggunakan data primer dan data sekunder. Data primer diperoleh dari hasil penyebaran angket atau kuesioner dengan responden sedangkan data sekunder diperoleh dari Dinas Pariwisata. Metode analisis data yang digunakan dalam penelitian ini adalah metode analisis deskriptif yang digunakan untuk mengetahui dan menjelaskan ancaman, kelemahan, kekuatan, dan peluang yang dihadapi dalam mengembangkan objek wisata, Kedua adalah analisis SWOT yang digunakan dalam mengidentifikasi faktor-faktor yang mempengaruhi proses pengembangan kawasan wisata Pantai Amal dan untuk menentukan strategi yang tepat dalam proses pengembangan tersebut dan Ketiga adalah metode AHP yaitu digunakan dalam menentukan strategi prioritas dari hasil yang telah ditentukan sebelumnya.

Objek, Lokasi Penelitian, dan Waktu Penelitian

Objek penelitian ini adalah
strategi peningkatan kualitas pengelolaan kawasan wisata. Lokasi penelitian ini di Pantai Amal Kecamatan Tarakan Timur Kelurahan Pantai Amal jalan Amal Lama, penelitian ini dilakukan selama satu bulan, dari bulan Januari hingga Februari 2018.

\section{Populasi dan Sampel}

Populasi dalam penelitian ini adalah wisatawan atau pengunjung objek wisata Pantai Amal dan para pengambil keputusan (stakeholder). Dan sampel dalam penelitian ini adalah wisatawan Pantai Amal yang dianggap layak dan memenuhi syarat sebagai sampel dan penelitian ini juga melibatkan para pengambil kebijakan sebagai sampel dalam menentukan strategi prioritas. Untuk penentuan jumlah sampel wisatawan Pantai Amal menggunakan teknik quoted accidental sampling. Teknik ini digunakan pada individu secara kebetulan dijumpai atau yang

dapat dijumpai dilokasi objek wisata sebagai wisatawan. Untuk menentukan jumlah sampel yang digunakan yaitu menggunakan rumus linier time function, sehingga jumlah sampel yang digunakan yaitu sebanyak 144 wisatawan.

\section{$\underline{\text { Jenis dan Sumber Data }}$}

Jenis data yang digunakan dalam penelitian ini adalah data primer dan data sekunder.

1. Data primer adalah data yang diperoleh langsung dari lokasi penelitian yang bertempat di Kawasan Wisata Pantai Amal Kota Tarakan. Data diambil menggunakan metode wawancara berdasarkan panduan 
pertanyaan dengan menggunakan kuisioner.

2. Data sekunder adalah data yang diperoleh melalui telaah bukubuku, literatur-literatur dan bacaanbacaan yang relevan dengan objekyang diteliti. Serta melengkapi data melalui instansiinstansi dan rujukan lain yang bersifat teoritis.

\section{$\underline{\text { Analisis Data }}$}

Metode analisis data yang digunakan dalam penelitian ini adalah metode analisis deskriptif, metode analisis SWOT dan metode AHP.

\section{$\underline{\text { Analisis Deskriptif }}$}

Metode analisis deskriptif digunakan untuk menjelaskan kondisi wisata Pantai Amal, dan faktor-faktor internal berupa kekuatan dan kelemahan dan juga menjelaskan faktor-faktor eksternal berupa peluang dan ancaman yang ada pada objek wisata Pantai Amal. Menjelaskan strategi peningkatan kualitas pengelolaan objek wisata Pantai Amal yang dirumuskan menggunakan analisis SWOT dan menjelaskan strategi yang menjadi prioritas dalam peningkatan kualitas pengelolaan wisata Pantai Amal Kota Tarakan.

\section{Metode Analisis SWOT}

Metode analisis data yang digunakan untuk mengidentifikasi faktor-faktor yang mempengaruhi proses pengembangan kawasan wisata Pantai Amal dan menentukan strategi dalam meningkatkan kualitas pengelolaan kawasan wisata tersebut. Dengan menganalisis faktor internal dan eksternal yaitu kekuatan, kelemahan, peluang dan ancaman yang ada pada objek wisata Pantai Amal.

$\underline{\text { Metode Analisis AHP }}$

Metode ini merupakan metode yang tepat untuk keputusan yang kompleks dan melibatkan perbandingan alat keputusan yang sulit untuk diukur secara kuantitas" (Wind dan Saaty, 1980). Juga dapat disebut sebagai metode kriteria penentuan keputusan untuk menentukan skala rasio dari AHP. Metode AHP menggunakan teknik pembobotan yang dilakukan oleh peneliti untuk memilih prioritas dari alternatif yang ada. Pada penelitian ini, alternatif yang ada terdiri dari beberapa kriteria yang dikelompokkan menjadi beberapa aspek-aspek yang diperoleh dari hasil pengelolaan data dengan menggunakan metode SWOT.

\section{HASIL DAN PEMBAHASAN}

$\underline{\text { Hasil }}$

\section{Analisis Deskriptif Faktor Internal dan Eksternal}

Berdasarkan hasil analisis pada objek wisata Pantai Amal terhadap kualitas pengelolaan kawasan wisata sebagai daya tarik ekowisata terdapat beberapa faktor yang mendorong dan menghambat baik itu dari internal maupun dari eksternal wisata Pantai Amal yang berbentuk kekuatan, kelemahan, peluang dan ancaman. 


\section{Potensi Objek Wisata Pantai Amal}

Potensi yang dimiliki oleh objek wisata Pantai Amal baik yang menjadi kekuatan dan peluang bagi wisata Pantai Amal. Adapun potensi yang dimiliki oleh objek wisata Pantai Amal yaitu, panorama pantai yang alami merupakan sebuah daya tarik bagi para wisatawan, keindahan panorama alam, hidangan laut yang dijual oleh rumah makan yang ada di sekitar objek, tempat parkir yang luas. Untuk peluang wisata Pantai Amal yaitu jumlah pengunjung yang akan terus meningkat, meningkatkan PAD Kota Tarakan, otonomi daerah, lapangan kerja yang baru dan kekayaan alam yang dimiliki oleh objek wisata Pantai Amal yang berada di daerah pesisir menghadirkan berbagai peluang dari potensi yang ada seperti, pemanfaatan hasil budidaya rumput laut yang bisa dijadikan berbagai macam produk makan yang memiliki nilai jual yang lebih tinggi dari nilai jual rumput laut mentah, yang mana peluang ini berdampak pada hadirnya produk-produk baru yang bisa dijadikan produk khas wisata Pantai Amal.

\section{Kendala Objek Wisata Pantai Amal}

Dibalik potensi yang dimiliki objek wisata Pantai Amal terdapat kelemahan dan ancaman yang menjadi penghambat bagi perkembangan wisata Pantai Amal, dengan adanya kelemahan dan ancaman bagi wisata Pantai Amal. Kelemahan dan ancaman yang ada yaitu, pengelolaan sampah yang belum terorganisir membuat kawasan wisata Pantai Amal menjadi terlihat kotor dan mengubah pemandangan pantai yang sejuk menjadi tidak nyaman, tidak adanya fasilitas pendukung seperti WC umum, tidak tersedianya ATM dan lampu penerangan disepanjang objek wisata yang belum ada membuat tingkat keamanan menjadi rendah.

Kelemahan lainya yaitu, Informasi mengenai perkembangan objek wisata yang masih kurang update membuat objek wisata Pantai Amal tidak dikenal secara luas, terbatasnya transportasi umum ketempat objek wisata, sehingga mengharuskan wisatawan menggunakan kendaraan pribadi, masyarakat yang kurang kreatif, terampil dalam berwawasan kepariwisataan menjadikan objek wisata menjadi kurang beragam karena tidak adanya kreasi maupun atraksi yang bisa dijadikan daya tarik. Untuk ancaman wisata Pantai Amal yaitu, seperti munculnya objek wisata baru dan berkembangnya objek wisata yang lebih professional, berkurangnya anggaran pemerintah sehingga biaya untuk pembangunan objek wisata Pantai Amal menjadi kurang dan kerusakan lingkungan akibat kegiatan pembangunan yang dilakukan masyarakat sekitar yang tidak berorientasi pada pembangunan berkelanjutan.

\section{Analisis SWOT}

Matriks Faktor Strategi Internal $\underline{\text { (IFAS) }}$

Berdasarkan perhitungan skor SWOT, diketahui skor dan pembobotan hasil perkalian dari 
bobot dan rating faktor strategi internal wisata Pantai Amal. Hasil tersebut menunjukkan bagaimana wisata Pantai Amal bereaksi terhadap faktor-faktor internalnya. Dari total skor internal yang dihasilkan, dapat mengetahui posisi kuadran wisata Pantai Amal dan dari skor total juga dapat digunakan untuk membandingkan kawasan wisata Pantai Amal dengan objek wisata lainyang ada di Kota Tarakan.

\section{Matriks Faktor Strategi Eksternal $\underline{\text { (EFAS) }}$}

Diketahui skor dan pembobotan hasil perkalian dari bobot dan rating faktor strategi eksternal wisata Pantai Amal. Hasil tersebut menunjukkan bagaimana wisata Pantai Amal bereaksi terhadap faktor-faktor eksternalnya. Dari total skor eksternal yang dihasilkan, dapat mengetahui posisi kuadran wisata Pantai Amal dan dari skor total juga dapat digunakan untuk membandingkan kawasan wisata Pantai Amal dengan objek wisata lain yang ada di Kota Tarakan.

\section{Matriks SWOT}

Berdasarkan kuadran di atas, strategi yang akan dirumuskan terletak pada kuadran I termasuk pada strategi Rapid growth strategy (strategi pertumbuhan cepat), yaitu suatu strategi untuk meningkatkan laju pertumbuhan kunjungan wisatawan dengan waktu lebih cepat (tahun kedua lebih besar dari tahun pertama dan selanjutnya), peningkatan kualitas yang menjadi faktor kekuatan untuk memaksimalkan pemanfaatan semua peluang. Berdasarkan hasil yang diperoleh dari matriks analisis SWOT maka dihasilkan strategi SO, WO, ST dan WT adapun strategi yang dihasilkan yaitu:

1. Strategi SO (StrengthOpportunity), strategi yang menggunakan kekuatan dan memanfaatkan peluang

a. Pengembangan objek wisata sebagai daya tarik ekowisata.

b. Mengembangkan dan menghadirkan produk baru khas wisata Pantai Amal.

c. Menciptakan iklim investasi yang kondusif.

d. Mengadakan diversifikasi kegiatan wisata atau atraksi wisata yang baru.

2. Strategi WO (WeaknessOpportunity), strategi yang meminimalkan kelemahan dan memanfaatkan peluang

a. Memperbaiki manajemen engelolaan Pantai Amal.

b. Melengkapi sarana dan prasarana dasar.

c. Meningkatkan pengelolaan informasi wisata Pantai Amal.

d. Pelatihan/pembinaan kerajinan rakyat berbasis potensi yang ada. Standarisasi keamanan

3. Strategi ST (Strength-Threats), strategi yang menggunakan kekuatan dan mengatasi ancaman.

a. Sosialisasi pengawasan dan perawatan kawasan objek wisata.

b. Studi banding dengan objek wisata lainnya.

c. Pengadaan kegiatan kesenian serbaguna. 
4. Strategi WT (Weakness-Threats), strategi yang meminimalkan kelemahan dan menghindari ancaman.
a. Sosialisasi pengawasan dan perawatan kawasan objek wisata.
b. Studi banding dengan objek wisata lainnya.
c. Pengadaan kegiatan kesenian serbaguna

5. Strategi WT (Weakness-Threats), trategi yang meminimalkan kelemahan dan menghindari ancaman.
a. Mengadakan kegiatan budaya tradisional khas Kota Tarakan.
b. Mengembangkan objek wisata yang berbeda dengan pesaing.
c. Perawatan secara berkala.
d. Mengoptimalkan lembaga pengelolah objek wisata.

\section{Metode Analisis AHP}

Dari alternatif strategi yang
telah dirumuskan kemudian
dikelompokkan kedalam dua level
yaitu, Level 1 merupakan kriteria
yang dikelompokkan dalam beberapa
aspek dan level 2 merupakan
subkriteria yang merupakan alternatif
strategi, yaitu sebagai berikut:

1. Aspek Manajemen
a. Memperbaiki manajemen pengelolaan Pantai Amal.
b. Pelatihan/pembinaan kerajinan rakyat berbasis potensi yang ada.
c. Studi banding dengan objek wisata lainnya.

d. Mengembangkan objek wisata yang berbeda dengan pesaing.

e. Mengoptimalkan lembaga pengelola objek wisata.

2. Aspek Ekonomi

a. Pengembangan objek wisata sebagai daya tarik ekowisata.

b. Mengembangkan dan menghadirkan produk baru khas wisata Pantai Amal.

c. Menciptakan iklim investasi yang kondusif.

3. Aspek Sosial Budaya

a. Mengadakan diversifikasi kegiatan wisata atau atraksi wisata yang baru.

b. Sosialisasi pengawasan dan perawatan kawasan objek wisata.

c. Mengadakan kegiatan budaya tradisional khas Kota Tarakan.

d. Pengadaan kegiatan kesenian serbaguna.

4. Aspek Infrastuktur
a. Melengkapi sarana dan prasarana dasar.
b. Meningkatkan pengelolaan informasi wisata Pantai amal.
c. Standarisasi keamanan.
d. Perawatan secara berkala.

\section{Matriks Perbandingan Berpasangan}

Matrik perbandingan Berpasangan Aspek-Aspek

Dari hasil pengelolaan data menjelaskan bahwa tingkat prioritas aspek-aspek berdasarkan dari tingkat terpenting dengan nilai tertinggi yaitu aspek manajemen dengan angka $(0,544)$, aspek infrastruktur $(0,311)$, aspek ekonomi $(0,097)$ dan 
aspek sosial udaya $(0,048)$ dengan inconsistency 0,09 .

\section{Matriks Perbandingan Berpasangan} Aspek Manajemen

Dari hasil data yang diolah menggunakan expert choice.11 menjelaskan bahwa strategi alternatif yang menjadi prioritas utama yaitu memperbaiki manajemen pengelolaan Pantai Amal dengan angka sebesar $(0,486)$, kemudian mengoptimalkan lembaga pengelolaan objek wisata $(0,272)$, pelatihan/pembinaan kerajinan rakyat berbasis potensi yang ada $(0,135)$, mengembangkan objek wisata yang berbeda dengan pesaing $(0,071)$ dan studi banding dengan objek wisata lainnya $(0,037)$ dengan inconsistency 0,07 .

\section{Matriks Perbandingan Berpasangan} $\underline{\text { Aspek Ekonomi }}$

Strategi alternatif $\begin{array}{r}\text { yang } \\ \text { adalah }\end{array}$
menjadi prioritas objek wisata sebagai
pengembangan obata
daya tarik ekowisata $(0,637)$,
menciptakan iklim investasi $(0,258)$
dan mengembangkan
dan menghadirkan produk baru khas
wisata Pantai Amal $(0,105)$ dengan
inconsistency 0,04 .

Matriks Perbandingan Berpasangan Aspek Sosial Budaya

Strategi alternatif yang menjadi prioritas dari aspek sosial budaya adalah mengadakan diversifikasi kegiatan wisata atau atraksi wisata yang baru $(0,398)$, Pengadaan kegiatan kesenian serbaguna (0,332), Mengadakan kegiatan budaya tradisional khas Kota Tarakan $(0,182)$ dan Sosialisasi pengawasan dan perawatan kawasan objek wisata $(0,088)$ dengan inconsistency 0,03 .

Matriks Perbandingan Berpasangan $\underline{\text { Aspek Infrastruktur }}$

Strategi alternatif yang
menjadi prioritas dari infrastruktur adalah Melengkapi sarana dan prasarana dasar $(0,586)$, Meningkatkan pengelolaan informasi wisata Pantai Amal (0,202), Standarisasi keamanan $(0,110)$ dan Perawatan secara berkala $(0,102)$ dengan inconsistency 0,07 .

$\underline{\text { Pembahasan }}$

Pembahasan Strategi Peningkatan $\underline{\text { Kualitas Pengelolaan }}$

1. Pengembangan objek wisata sebagai daya tarik ekowisata.

Strategi dalam meningkatkan kualitas pengelolaan kawasan wisata Pantai Amal yaitu, dengan pengembangan objek wisata sebagai daya tarik ekowisata, konsep pengembangan yang dilakukan untuk objek wisata Pantai Amal bersifat berkelanjutan yang mendukung pelestarian lingkungan alam dan budaya, dan secara tidak langsung melibatkan masyarakat untuk partisipasi dalam pengelolaannya dengan pemanfaatan ekonomi wilayah alam yang serasi dengan perlindungan lingkungan alam yang sesuai dengan prinsip ekowisata.

2. Mengembangkan dan menghadirkan produk baru khas wisata Pantai Amal. 


\begin{abstract}
Alternatif strategi selanjutnya dalam meningkatkan kualitas pengelolaan kawasan wisata Pantai Amal sebagai daya tarik ekowisata yaitu dengan mengembangkan produk wisata yang sudah ada dan menghadirkan produk-produk baru khas wisata Pantai Amal dengan memanfaatkan potensi objek wisata yang melibatkan masyarakat dalam menciptakan daya tarik ekowisata.

3. Menciptakan iklim investasi yang kondusif.
\end{abstract}

Strategi alternatif dalam meingkatkan kualitas pengelolaan kawasan wisata Pantai Amal yaitu menciptkan iklim investasi yang kondusif merupakan salah satu langka dalam menarik investor untuk menanamkan modalnya, dengan kondisi objek wisata yang kondusif dan didukung dengan sarana dan perasarana dasar yang memadai memungkinkan bagi investor untuk melakukan kerja sama dalam mengembangkan objek wisata Pantai Amal.

4. Mengadakan diversifikasi kegiatan wisata atau atraksi wisata yang baru.

Dengan melakukan

diversifikasi atau penganekaragaman kegiatan objek wisata atau atraksi maupun produk dan jasa, merupakan strategi dalam meningkatkan daya tarik objek wisata Pantai Amal agar dapat meningkatkan jumlah kunjungan dan merupakan daya tarik bagi ekowisata yang mampu membuat objek wisata Pantai Amal menjadikan pilihan destinasi wisata di Kota Tarakan bagi wisatawan lokal maupun wisatawan asing.
Pembahasan Prioritas Strategi $\underline{\text { Alternatif }}$

1. Aspek manajemen

Alternatif strategi yang menjadi prioritas pada aspek manajemen adalah memperbaiki manajemen pengelolan pengelolaan Pantai Amal karena untuk manajemen pengelolaan kawasan wisata Pantai Amal masih sangat kurang optimal sehingga berdampak pada kualitas pengelolaan kawasan wisata.

2. Aspek ekonomi

Alternatif strategi yang menjadi prioritas pada aspek ekonomi adalah mengembangkan objek wisata sebagai daya tarik ekowisata, karena sampai saat ini pengembangan objek wisata yang dilakukan masih minim sehingga urang maksimal dalam menghadirkan produk baru, rendahnya terhadap pendidikan lingkungan bagi pengelola dan pengunjung, kurang dirasakan manfaatnya bagi masyarakat lokal dan kurang memberikan kepuasan bagi wisatawan.

3. Aspek sosial budaya

Alternatif strategi yang menjadi prioritas pada aspek sosial budaya adalah mengadakan diversifikasi kegiatan wisata atau atraksi wisata yang baru, karena atraksi dan kegiatan

yang ada di objek wisata Pantai Amal masih sangat kurang sehingga daya tarik wisata Pantai Amal menjadi kurang, bagi wisatawan untuk menjadikan wisata Pantai Amal menjadi tempat tujuan destinasi 
4. Aspek infrastruktur

Alternatif strategi yang menjadi prioritas pada aspek infrastruktur adalah melengkapi sarana dan perasarana dasar, karena penyediaan sarana dan perasarana dasar di objek wisata Pantai Amal masih sangat kurang seperti, penyediaan WC umum dan sarana pendukung seperti ATM yang menjadi kebutuhan bagi wisatawan yang seharusnya dilengkapi.

\section{KESIMPULAN DAN SARAN}

$\underline{\text { Kesimpulan }}$

Dari hasil penelitian dapat disimpulkan bahwa:

1. Dari hasil identifikasi faktor internal dan eksternal dapat dirumuskan strategi untuk peningkatan kualitas pengelolaan wisata Pantai Amal, dan didapatkan strategi alternatif yang dapat digunakan dalam peningkatan kualitas pengelolaan berdasarkan hasil olah data dan kondisi wisata Pantai Amal adalah strategi SO Atau strategi Rapid growth strategy (strategi pertumbuhan cepat) yaitu strategi meningkatkan laju pertumbuhan kunjungan wisatawan dengan waktu lebih cepat (tahun kedua lebih besar dari tahun pertama dan selanjutnya), peningkatan kualitas yang menjadi faktor kekuatan untuk memaksimalkan pemanfaatan semua peluang.

2. Strategi prioritas yang dilakukan untuk meningkatkan kualitas pengelolaan kawasan wisata Pantai Amal yaitu sebagai berikut, pertama aspek manajemen dengan kriteria berdasarkan tingkat prioritasnya yaitu, memperbaiki manajemen pengelolaan Pantai Amal, kemudian mengoptimalkan lembaga pengelolaan objek wisata, pelatihan/pembinaan kerajinan rakyat berbasis potensi yang ada, mengembangkan objek wisata yang berbeda dengan pesaing dan studi banding dengan objek wisata lainnya. Kedua aspek infrastruktur dengan kriteria berdasarkan tingkat prioritasnya yaitu, melengkapi sarana dan prasarana dasar, meningkatkan pengelolaan informasi wisata Pantai amal, standarisasi keamanan dan perawatan secara berkala. Ketiga aspek ekonomi dengan kriteria berdasarkan tingkat prioritasnya yaitu, pengembangan objek wisata sebagai daya tarik ekowisata, menciptakan iklim investasi, dan mengembangkan dan menghadirkan produk baru khas wisata Pantai Amal. Keempat aspek sosial budaya dengan kriteria berdasarkan tingkat prioritasnya yaitu, mengadakan diversifikasi kegiatan wisata atau atraksi wisata yang baru, pengadaan kegiatan kesenian serbaguna, pengadaan kegiatan budaya tradisional khas Kota Tarakan, dan sosialisasi pengawasan dan perawatan kawasan objek wisata.

$\underline{\text { Saran }}$

Berdasarkan kesimpulan di atas maka saran bisa menjadi masukan bagi pengelola objek wisata dan pemerintah terkait guna lebih 
meningkatkan kualitas objek wisata tersebut sehingga biasa menjadi sumber pendapatan pemerintah dan masyarakat.

\section{DAFTAR PUSTAKA}

Bapeda dan BPS Kota Tarakan, Kota Tarakan Dalam Angka 2017, BPS Kota Tarakan.

Badan Pusat Statistik Kota Tarakan. 2018.

Tarakan Dalam Angka 2017. Gambaran Umum Wisata Kota Tarakan. Parlindungan,

Djamhur Hamid Dan Topowijono. 2016. Pengembangan Objek Wisata Pantai Amal Di Kota Tarakan (Studi Kasus Pada Dinas Kebudayaan Pariwisata Pemuda Dan Olahraga Kota Tarakan).Jurnal Fakultas Ilmu Administrasi. (Volume. 32 No. 1; 53-57).

Coyle, G. 2004. The Analtic Hierarchy Process (AHP). Amerika Serikat: Pearson Education. Damanik, Janianton dan Waber,

Helmut. 2006. Perencanaan Ekowisata Dari Teori

Ke Aplikasi. Yogyakarta: Vinipritindo.

Dinas Kebudayaan, Pariwisata, Pemuda dan Olahraga.

2017. Data Jumlah Pengunjung Objek Wisata Pantai Amal. Kota Tarakan.

Djoeffan, Sri Hidayati Dkk. 2010. Strategi Pengelolaan Kawasan Wisata Cagar Budaya Karangkamulyan Di Kabupaten Ciamis. Prosiding. Bandung: Hlm.205-229.
DPM-PTSP (Dinas Penanaman Modaldan Pelayanan Terpadu Satu Pintu). Sektor Perikanan. Kota Tarakan. 
